\title{
Paideusis
}

\section{Glorious Dreams and Harsh Realities: The Roles and Responsibilities of the Teacher from a Deweyan Perspective}

\section{Michael J.B. Jackson and Douglas J. Simpson}

Volume 8, Number 2, 1995

URI: https://id.erudit.org/iderudit/1073255ar

DOI: https://doi.org/10.7202/1073255ar

See table of contents

Publisher(s)

Canadian Philosophy of Education Society

ISSN

0838-4517 (print)

1916-0348 (digital)

Explore this journal

Cite this article

Jackson, M. \& Simpson, D. (1995). Glorious Dreams and Harsh Realities: The Roles and Responsibilities of the Teacher from a Deweyan Perspective.

Paideusis, 8(2), 15-31. https://doi.org/10.7202/1073255ar viewed online.

https://apropos.erudit.org/en/users/policy-on-use/ 


\title{
Glorious Dreams and Harsh Realities: The Roles and Responsibilities of the Teacher from a Deweyan Perspective
}

\author{
Michael J. B. Jackson, Queen's University \\ Douglas J. Simpson, Texas Christian University
}

Everything the teacher does, as well as the manner in which he does it, incites the child to respond in some way or other, and response tends to set the child's attitude in some way or other. (HWT, 59)

. . the fundamental issue is not of new versus old education nor of progressive against traditional education but a question of what anything whatever must be to be worthy of the name education. (EE, 90)

One thing which characterizes education in the last decade or so is a widespread but not new belief that it must be reformed. New are the extent of discontent and disagreement among parents, voters, board members, administrators, and teachers and the range of proposals for reform. A recent Royal Commission found an "unexpected lack of consensus . . . in Ontario on just about every aspect of the education system . . . about what the major problems were and ... about what the solutions were" even though "there is no serious evidence that our schools are failing our kids any more or less than they ever have" (For the Love of Learning, 1994, xii, 3).

Popular disenchantment is expressed in endless discussion, publications, and legislation concerning the desirable characteristics of classrooms, schools, districts, and programs. Proposals range from Charter Schools based on the Paideia program to customer-oriented models from business. ${ }^{1}$ What is discouraging is their fragmented, incoherent, and often contradictory conception of education and its problems and their identification of single causes and simple panaceas-for example, site-based management, national testing, a common curriculum, privatization, skills for employment and national economic advantage, and cooperative learning styles. Intuitively, but also from experience, we know that all this is wrong. ${ }^{2}$ Education is embedded in a multiplicity of complex and seemingly conflicting contexts. The problems, then, are not simple, and so, a comprehensive conception of them and of the activities of education is needed. Reflecting this insight is widespread interest in dramatic, radical, sweeping but equally single reconceptualizations-for instance, rethinking the roles of educational technology, the nature of knowledge, our conception of intelligence, the changed nature of society, the relationship of schools to parents and the community, the responsibilities of principals and supervisory staff, possibilities for alternative licensing programs and accrediting associations, and new roles for teachers as reflective practitioners, researchers, and professionals. Sometimes the single panaceas and radical rethinking go hand-in-hand: the information age and the learning society, for example, requiring a computer for every child.

Surprisingly, very little attention is given to the roles and responsibilities of teachers whose everyday activities ultimately determine whether any reform in education is effective. Except for research on effective teaching and classroom processes (Buchmann \& Floden, 1993; Hawley, Rosenholtz, Goodstein \& Hasselbring, 1984), general educational renewal projects (Fullan, 1991; Good- 
lad, 1990), pedagogic thoughtfulness (van Manen, 1991) and ethical interpretations of the traits desirable in a teacher (Goodlad, Soder, \& Sirotkin, 1990; Hare, 1993), reformers' contributions to better understanding the actual roles and responsibilities of the classroom teacher are limited. There are accounts of how teachers should be prepared in university (Dill, 1990), how they should enable students to create their own knowledge (Perkinson, 1993), how they should help emancipate students and society from class, gender and ideological blinders (Freire, 1970; Giroux, 1988; hooks, 1994), why they should have a differentiated set of career options (Holmes Group, 1986), and whether they should become professionals (Covert, 1993; Socket, 1993). At the other extreme are immediately practical proposals for specific behaviour management, conflict resolution and cooperative learning strategies and techniques, among others, which appeal because they "work."

Despite many contributions, the lack of discussion of the roles and responsibilities of teachers, the kinds of activities they should engage in as professionals and the considerations pertinent in making pedagogical decisions is remarkable. It is as if they were so familiar that we find their roles simple, commonplace, and unproblematic, believing that we know what there is to know-until, that is, we try to explain our reactions or understand those of others in complicated and controversial cases (see Hare, 1990). Then, we seek careful analysis of those things teachers do, ought to do, or refrain from doing-their roles and responsibilities. So we believe it would be helpful to reconsider the writings of a noted reformer who refined his thoughts about "the province and office of the teacher" (EE, 58) over sixty years of systematically studying, observing, and trying out ideas. Specifically, we believe that Dewey's notion of community and his analogies for teaching help to understand the point of reform and show the inappropriateness of simple solutions by drawing attention to the complexity of the context and the need to reconcile potentially conflicting demands hidden in the familiarity of the role and the institution.

Dewey saw that sweeping changes characterized his time, that educational reforms were required, and that rethinking philosophy, education, and social issues was needed: "... practical changes cannot take place without demanding an educational reformation to meet them, and without leading men to ask what ideas and ideals are implicit in these social changes, and what revisions they require of the ideas and ideals which are inherited from older and unlike cultures" (DE, 331). He knew, too, the practical realities of reform through elections, community projects, publishing, and his laboratory school. For him, social and educational philosophy begins from concrete problematic situations (DE, 96) but looks beyond the specifics. He believed that education consists in growth and makes possible further growth through increased power and control (EE, chap. 3; DE, chap. 4), that the thoughtful, informed study of social problems and their origins is the key to personal educational progress and progressive social reform, and that such progress is possible and worth pursuing because by nature human beings are social (MPE, chap. 2).

\section{The Teacher and the Community}

The concept of community-"community-centred" rather than "childcentred" education-dominates Dewey's educational and social thinking, playing several roles and raising perplexing questions about the community's control 
of schools and the use of schools for social criticism and reconstruction. Central to this discussion and to the complexity of Dewey's position is his notion of educational communities. For our purposes, we will distinguish four overlapping communities: the class, school, neighbourhood, and larger social environment.

For Dewey, the teacher cannot be an isolated entity, an island, in conception or in practice, personally or educationally but is a member of an informal educational community composed of parents, neighbours, students, workers, employees, educators, and others, and an environment that includes factories, businesses, parks, streets, houses, vehicles, trees, and so on-"whatever conditions interact with personal needs, desires, purposes, and capacities to create the experience which [a child has]" (EE, 44). This neighbourhood community is unusually important for "every place in which men habitually meet, shop, club, factory, saloon, church, [or] political caucus is perforce a schoolhouse" (MW, 7, 304). Thus, the ". . . teacher should become intimately acquainted with the conditions of the local community, physical, historical, economic, occupational, etc., in order to utilize them as educational resources" (EE, 40). In a sense, professional preparation in "school specific environmental understanding" can only begin after accepting a particular teaching assignment in an identifiable school and community when the teacher learns about the "schoolhouses" scattered throughout the community. This may lead to a current and-for Dewey-central social and philosophical question: each teacher-ultimately each school and district-must decide whether "to use industry for education or let industry use education for its own purposes" (MW, 7, 385). ${ }^{3}$

Dewey's thoughts on the neighbourhood community today seem both radical and commonplace:

The life which men, women and children actually lead, the opportunities open to them, the values they are capable of enjoying, their education, their share in all the things of art and science are mainly determined by economic conditions. Hence we can hardly expect a moral system which ignores economic conditions to be other than remote and empty. (QC; $L W, 4,225)$

This is the social activist who worked at Hull House and for the election of "socialist" candidates in the 1930s and spoke on ethnic and women's issues: economic conditions were both a moral and an educational issue. Thus, Dewey's theory that economic factors and social class are major determinants of much else in society is employed by him to broaden the social and educational responsibilities of teachers rather than to limit the effect of educational institutions and personnel.

He also tempered reform proposals with practical "realism": "Without the support of the progressive and enlightened forces of the community, . . . all their [teachers'] best plans and ideas would have had little or no effect on the education system" (Dworkin, 129). Though he thought that in the community teachers should be aggressive advocates for the needs of children and youth, he lamented that in fact in progressive social reforms, even those involving children, "the initiative in the agitation of these questions and the formation of public opinion has to a surprisingly small extent proceeded from teachers" (MW, 7, 110). Teachers are not to be just observers of the community that partially educates children and young people but members involved in the 
"proper protection and ... proper nurture" of the young, two responsibilities which constitute "the most fundamental care of society": they "bear a responsibility as leaders, as directors in the formation of public opinion." (MW, 7, 110)

We might see antecedents of critical pedagogy and commitments to empowerment in these thoughts. Yet, on professional responsibility, Dewey appears concerned that the influence of teachers be neither underestimated nor overestimated-even within the school:

It is absurd to say . . . that the teachers are responsible for the evils, the backwardness, the overscholasticism of the present. Teachers must bear our share of the blame; ... but we are far from being exclusively or mainly to blame. The teachers are not in control of the schools. The schools are in the control of the community, and if they have carried out an overacademic and an overscholastic policy, it is because that is as far as the average public sentiment of the average community has advanced up to the time. (MW, 7 89)

Dewey's belief that schools were controlled by communities may seem quaint, timid, or overly conservative but not to those who have recently encountered a controversy that excited the parents in a school neighbourhood. ${ }^{4}$ But Dewey believed that teachers should be actively shaping the views of the community controlling the schools. Social activism of a sort is a teacher's professional as well as civic responsibility:

I know there are some who think that the implications of what I have said point to abstinence and futility ... . But I am surprised when educators adopt this position, for it shows a profound lack of faith in their own calling. It assumes that education as education has nothing or next to nothing to contribute; that formation of understanding and disposition counts for nothing; that only immediate overt action counts and that it can count equally whether or not it has been modified by education. (Ratner, 696)

By extrapolation, with his involvements and views of the role of economic factors in determining social conditions, that responsibility extends to another greater environment or community: the province, state, and nation that have an impact on cities, neighbourhoods, schools, and classrooms. Though we focus on the immediate community that surrounds the school, and though the school itself as a community and the classroom as a learning community, there is in an important underlying sense only one community:

As an individual passes from one situation to another, his world, his environment, expands or contracts. He does not find himself living in another world but in a different part or aspect of one and the same world. What he has learned in the way of knowledge and skill in one situation becomes an instrument of understanding and dealing effectively with the situations which follow. (EE, 44)

This notion reflects Dewey's account of habit and the experiential continuum and his principles of continuity and pedagogical interaction-these being vital in the teacher's wisely selecting and productively utilizing environments that are educative in promoting growth rather than noneducative or miseducative in stifling it (cf. EE, chaps. 2-3).

There is an inevitable ambiguity: people are social, and so, in a sense, any 
social setting in which they find themselves is a kind of community (PP, 12ff.). Dewey's term "environment" may be better here, for some environments are more like true communities than others-as in the "community spirit" of a town or a group. A town which is "not much of a community" still remains a community, a minimal social environment-just as a school, no matter how bad, remains in a sense a learning community - but not a full, authentic community. "Community," then, can function as an evaluative term: a "real community" with "real community spirit" with a care and concern for the "neighbours" and "the neighbourhood." Such neighbours are not just people who live next door.

Dewey moved from the neighbourhood community or communities surrounding the school to two learning communities central to the teacher: the school as a unit (EE, 55) and the individual class as a social group (EE, 59). $\mathrm{He}$ often spoke of the business of the school and the teacher's contributions to the overall educative environment of the school, contrasting some types of school organization with more natural groups and activities where the appropriate structure and order were spontaneous, natural, and genuine, as in matters of discipline. While it did constitute an environment,

[t]he [traditional] school was not a group or community held together by participation in common activities. Consequently, the normal, proper conditions of control were lacking. Their absence was made up for, and to a considerable extent had to be made up for, by the direct intervention of the teacher, who, as the saying went, "kept order." He kept it because order was in the teacher's keeping, instead of residing in the shared work being done. (EE, 55)

Similarly, in the classroom community, Dewey distinguished traditional schools where "pupils were a class rather than a social group, [and so,] the teacher necessarily acted largely from the outside, not as a director of exchange in which all had a share" (EE, 59). The challenge is not to gain commitment to the community but to design a legitimate community to which commitment is spontaneous, natural, and appropriate rather than enforced. A community is genuine when it recognizes and responds to the genuine needs of its members. It is, then, natural rather than alien, external, or arbitrary. The challenge for a Deweyan teacher is to create school and classroom communities which exist for the genuine growth and enrichment of the lives of their members. His analysis of the dynamics of a class shows how vital the concept of social group or community is to his educational theory and how decisive the shared purposes of the group are. A teacher as a member of a smaller learning community, such as a class, is a member of a group designed and held together by an intention to learn together. The teacher is, therefore, an insider, not an "external boss or dictator" (EE, 59).

A school group is one designed for learning but for a kind of learning which makes possible genuine educational growth. While there is no abdication of the teacher's authority, her powers are not unlimited nor arbitrary, a concept to be understood in terms of their appropriateness to the purposes of the group: "In reality, the teacher is the intellectual leader of a social group ... a leader, not in virtue of official position, but because of wider and deeper knowledge and matured experience" (HWT, 273). Within both the neighbourhood and the broader community, the teacher's role is that of an informed, educated, and thoughtful participant, a member who as a social being has a legitimate interest 
in the nature of that community and who is a potential leader at least in forming public opinion. So, experiences that come from within the school and classroom communities can provide insights which will be of pedagogic and curricular value. Within the school and the classroom, the teacher is again a more knowledgeable and experienced community member and a leader.

Distinguishing communities helps to identify and explain the teacher's central role and to clarify questions about it and understand its conflicts. Do cooperative learning and conflict resolution strategies simply improve student learning or build a classroom and school community? Do they do it for all students or only certain ones? And do they covertly promote non-competitive moral values which, conceivably, might transform our larger society? Conversely, do customer-oriented approaches in school import into classrooms values which are dysfunctional there? The teacher has a definite, essential, and partially prescribed role to promote students' growth, but no simple, context-free answer can be given to the question of the teacher's role. The role is not one because the context is not one, and the interactions are complex and often poorly understood. This explains, in part, why Dewey stressed that teachers need to be be sophisticated in making professional judgments.

A possibility partly neglected in Dewey's conception of different communities is that their goals may simply be opposed: the larger community may favour employment-related competencies and national assessments and standards which are unhelpful in promoting critical thinking, broad general culture, and educational growth in the classroom and school communities. Nevertheless, Dewey's analysis helps to identify the locus of the dispute: different communities, defined by different purposes, may come into conflict.

\section{Growth and the Experiential Continuum}

Two of Dewey's educational principles relate to continuity and interaction in experience. Unwilling to separate pedagogical responsibilities from these communities, he saw education as a seamless fabric. Separating subjects into discrete domains for children was similarly alien to his thinking as foreign to the way they (and to a lesser degree others) usually learn; it was foreign to experience. Though the academic disciplines have a fundamental epistemological and so educational place as "funded experience," school learning should be an integrated continuum of experience flowing out of informal learning experiences enjoyed at home and in the neighbourhood.

His accounts of interaction and habit and of how learning occurs within the home (SS/CC, 34-35) are the basis of his thinking. At home, the child is naturally involved in the activities of the family; the wise mother observes the wants and needs of her child and responds in light of her own experience and that of others to create an orderly and promising setting for the child's growth (EE, 41-42). Past, present, and future experience, individual and collective, are integrated. Central is Dewey's understanding of habit and his opposition to an atomistic, behaviourist psychology (1896). Every past experience changes the person, and so, present and future experiences: "every experience both takes up something from those which have gone before and modifies in some way the quality of those which come after" (EE, 35). Words like "integrated," "interaction," and "continuum," reveal more than one element: that which flows out flows also into something else. 
So Dewey associates education with growth, continued capacity for growth and the quality (EE, 27-28) of experience, moral and educational: "the question is whether growth in this direction promotes or retards growth in general ... the occasions, stimuli, and opportunities for continuing growth in new directions" (EE, 36). If these principles of continuity and interaction in experience frame a context and, if we think of growth as a measure of the educational quality of an experience, Dewey's analogies enable us especially to see the teacher at work in the smallest of the communities, the classroom, and to appreciate the kinds of things the Deweyan teacher should be prepared to understand and do-her appropriate roles and responsibilities.

\section{Seven Analogies}

Besides presenting the roles and responsibilities of the teacher as a member of the school community, a student of its workings, a protector of the young, a builder of public opinion and a community leader, Dewey described the teacher explicitly or implicitly in terms of analogies. Each describes an integral part of the roles and responsibilities of a professional educator active in the affairs of the four kinds of communities. We have selected seven as particularly helpful: learner, intellectual leader, partner and guide, wise parent, social servant, prophet, and artist.

Learner. Talk of the teacher as life-long learner, in-service education, changing educational expectations, professional growth and development, and periodic recertification makes the concept of the teacher as learner central; it undergirds all Dewey's other notions of the teacher, giving precision to potential cliches. First, though seeming initially removed from the classroom, as a concerned citizen, the teacher is a learner, studying the larger community, its interactions and its problems and considering possible solutions and action. The teacher is observant and curious: observing "what is going on more widely and more minutely and then select[ing] more carefully from what is noted just those factors which point to something to happen' (DE, 146) but reflectively for

... observation alone is not enough. We have to understand the significance of what we see, hear, and touch ... the consequences that will result when what is seen is acted upon." (EE, 68)

These are marks of any educated, reflective, genuine participant in a community.

Yet, they are the key: within the school community, the teacher is similarly a citizen and student-involved, committed, caring, and sharing the common goal of establishing an environment conducive to educational growth. As within the class, the teacher should understand that the student is also a teacher and that "upon the whole, the less consciousness there is, on either side, of either giving or receiving instruction, the better" (DE, 160). In class, both are exploring the subjects studied, one admittedly with more experience and so responsibility. Both have a special commitment to the success of the enterprise: beyond knowing about the subject and learning from the students as they raise questions and suggest answers to problems, the teacher should learn about the students as learners and members of the group both here and in their free activity $(\mathrm{EE}, 62)$. The teacher may be viewed as a researcher, not in any esoteric or mysterious sense but as searching, inquiring, and analysing the behaviour of students, looking to know them better and so to teach them better. "The act of 
looking" is "an act of research" (HWT, 13); indeed, "all thinking is research" (DE, 148).

As an experienced, committed member of the group, the teacher is a professional keeping abreast of her field, recognizing "the responsibility for constant study of school room work, [and] the constant study of children, of methods, of subject matter" (MW, 7, 109). This shows in-service and professional development at its best (cf. Fullan, 1991)-and typical requirements for course work and periodic recertification as policing measures substituting for effective professionalism. Dewey had an intense distaste for students' "rehearsing material in the exact form in which the older person [teacher or adult] conceives it" (DE, 304), "a diet of predigested materials" (EE, 46), partly because "teaching then ceases to be an educative process for the teacher" (DE, 304).

Intellectual leader. The teacher learning along with her students may seem again to abdicate directive responsibilities and authority even if her greater experience and knowledge are noted. This criticism was at the crux of the anti-intellectual disasters attributed to progressive education. Just as the teacher was to help to build informed public opinion, create consensus, and initiate progressive social reform in the larger communities, so in class, as an intellectual leader, she has an active, involved social role. She is not simply "in charge"-in authority to impose her will, keep order, or direct-but an authority with resources, experience, and expertise to facilitate the common ends for which she and the students are there. As well as carefully selecting and arranging nurturing educative conditions, the teacher has to protect students from noneducative and miseducative stimuli-educationally pointless and dogmatic positions which discourage inquiry, for example (HWT, 40).

To "take a positive and leading share in the direction of the activities of the community of which he is a member" (EE, 58), the teacher must be an active selector and thoughtful arranger of stimuli and conditions and capable of recognizing those with educative potential and both the immediate and the longterm needs of students (MW, 7, 197). And fuller and richer the experience of the teacher, the more adequate his own knowledge of 'traditions' the more likely is he, given the attitude of participator instead of that of master, to use them in a liberating way"' (Ratner, 626-627).

So as an intellectual leader respecting the principles of continuity and interaction in experience in order to promote growth, the teacher has

the duty of instituting a much more intelligent, and consequently more difficult, kind of planning. He must survey the capacities and needs of the particular set of students with whom he is dealing and must at the same time arrange the conditions which provide the subject-matter or content for the experiences that satisfy these needs and develop these capacities. The planning must be flexible enough to permit free play for individuality of experience and yet firm enough to give direction towards continuous development of power. (EE, 58)

No experience is educative that does not tend both to knowledge of more facts and entertaining of more ideas and to a better, a more orderly, arrangement of them. (EE, 82)

Dewey was far from advocating a watered-down curriculum or an abdication of intellectual leadership: 
It is essential that the new objects and events be related intellectually to those earlier experiences, and this means that there be some advance made in conscious articulation of facts and ideas. It thus becomes the office of the educator to select those things within the range of existing experience that have promise and potentiality of presenting new problems which by stimulating new ways of observation and judgments will expand the area of further experience. He must constantly regard what is already won not as a fixed possession but as an agency and instrumentality for opening new fields which make new demands upon existing powers of observation and of intelligent use of memory. Connectedness in growth must be his constant watchword. (EE, 75)

Partner and guide. One should not underestimate the novelty in Dewey's conception of educational leadership nor the extent to which he thought it rooted in a better understanding of the new scientific method that makes thinking effective or successful. 5 Dewey expected the teacher to be an intellectual leader, and so, to use the scientific method in her work "as the pattern and ideal of intelligent exploration and exploitation of the potentialities inherent in experience" (EE 86), to exemplify it and to adapt it to students as they learn to engage in "the formation of ideas, acting upon ideas, observation of the conditions which result, and organization of facts and ideas for future use" (EE, 88). Authority in this kingdom of reason is democratic; and, in the process of assisting students in their development, the teacher is "not a magistrate set on high and marked by arbitrary authority but ... a friendly co-partner and guide" (Archambault, 10). Moreover, as "guide and director," though the teacher "steers the boat, ... the energy that propels it must come from those who are learning" (HWT, 36); she cannot overcome that force or steer squarely into the wind. Thus,

It is possible . . . to abuse the office [of teacher], and to force the activity of the young into channels which express the teacher's purpose rather than that of the pupils. But the way to avoid this danger is not for the adult to withdraw entirely ... . The teacher's suggestion is not a mold for a cast-iron result but is a starting point to be developed into a plan through contributions from the experience of all engaged in the learning process. The development occurs through reciprocal give-and-take, the teacher taking but not being afraid to give. The essential point is that the purpose grow and take shape through the process of social intelligence. (EE, 71-72)

Thus, communitarian traits of shared, cooperative study also characterize recent methods in cooperative learning, restoring the school "sin" of helping your neighbour to a productive and natural act, a social duty in a democratic community.

Wise parent. The teacher as concerned with the child's growth and with protecting the child against noneducative and miseducative influences leads readily to one of Dewey's favourite analogies, the wise parent motivated by the concern of all good parents: "What the best and wisest parent wants for his own child, that must the community want for all of its children. Any other ideal for our schools is narrow and unlovely; acted upon, it destroys our democracy" (SS/CC, 7). Such a teacher may well temper a detached purely professional attitude with caring and building rapport with parents and the home.

General descriptions of learning in the home (RIP, 92), a natural learning community, led Dewey to the ideal home as the model for the ideal school:

8(2), (Spring) 1995 
We find the child learning through the social converse and constitution of the family. There are certain points of interest and value to him in the conversation carried on: statements are made, inquiries arise, topics are discussed, and the child continually learns. He states his experiences, his misconceptions are corrected. Again the child participates in the household occupations, and thereby gets habits of industry, order, and regard for the rights and ideas of others, and the fundamental habit of subordinating his activities to the general interest of the household. Participation . . . becomes an opportunity for gaining knowledge. (SS/CC, 34-35)

Interest and motivation are not a problem and learning is spontaneous, directed, and centred on the child as a member of a familial community. The educator is "doing systematically and in a large, intelligent, and competent way what for various reasons can be done in most households only in a comparatively meagre and haphazard manner" (SS/CC, 35).

Like a wise mother, the teacher should draw upon "past experiences of experts as well as her own" and utilize "the funded experience of the past," our traditions and intellectual heritage, as she goes about her duties (EE, 42). But she is not to make a "fetish" of advice and directions and abandon "personal judgment" (EE, 43)-as a wise parent neither responds to a baby's every cry, nor slavishly follows a general, pre-established pattern (EE, 41-42). Here we have the ability of the teacher to make informed professional judgments-an important ability for Dewey who wanted any reflective person to be such a thinker (EE, 35; HWT, 125). This capacity for judgment distinguishes the artist from the "intellectual bungler" (HWT, 123-124).

Yet, the teacher is not the child's parent and school is not home, distinctions that concern us now that family structure is changing and the school is by request or default taking on tasks which might earlier have been done at home. Dewey thought his a time of profound social change but may not have foreseen the extent of the changes.

Social servant. With the limited possible influence of the school and its teachers and the restricted involvement in social reform that Dewey finds typical of teachers, it is easy to see the teacher as a social servant. But, as a leader who identifies community problems, helps build a new social consensus, and initiates progressive reforms, she can hardly be simply bound to put forward and represent uncritically her employer's ideas. She is rather employed by the community to improve it, "a social servant set apart for the maintenance of proper social order and the securing of the right social growth ... engaged, not simply in the training of individuals, but in the formation of the proper social life" (Archambault, 439). She is engaged in moral education and encouraging critical thought; and we are rightly interested to know what Dewey means by "proper social life," "proper social order," and "right social growth."

For Dewey, a proper social life or a genuine community is democratic in its concern for the growth of its members. Here his educational and political philosophy interact for, like a genuine education, a genuine community promotes growth.

The devotion of democracy to education is a familiar fact. The superficial explanation is that a government resting upon popular suffrage cannot be successful unless those who elect and who obey their governors are educated. Since a democratic society repudiates the principle of external au- 
thority, it must find a substitute in voluntary disposition and interest; these can be created only by education. But there is a deeper explanation. $A$ democracy is more than a form of government; it is primarily a mode of associated living, of conjoint communicated experience. The extension in space of the number of individuals who participate in an interest so that each has to refer his own action to that of others, and to consider the action of others to give point and direction to his own, is equivalent to the breaking down of those barriers of class, race, and national territory which kept men from perceiving the full import of their activity. (DE, 87; italics added)

Talking of what he believes are the fundamental values of American democracy, "freedom of belief, of speech, of the press, of assembly, and of petition ... [ [which are] aspects of what I have called intellectual freedom, but which perhaps would better be called moral freedom ....," he adds

The ultimate stay and support of these liberties are the schools. For it is they which more than any other single agency, are concerned with the development of free inquiry, discussion and expression." (Ratner; 723, italics added)

Democracy may be a desirable or natural social order, creating a genuine fulfilling community, but people are not born committed to it or knowing how to participate.

The best guarantee of collective efficiency and power is liberation and use of the diversity of individual capacities in initiative, planning, foresight, vigour and endurance. Personality must be educated, and personality cannot be educated by confining its operations to technical and specialized things, or to the less important relationships of life. Full education comes only when there is a responsible share on the part of each person, in proportion to capacity, in shaping the aims and policies of the social groups to which he belongs. This fact fixes the significance of democracy. (RIP, 209)

Seeing the school and classroom as communities takes on both pedagogic and civic importance: in a genuine community, for Dewey, civic education, moral education, political education and general education become of a piece. "The educative process is all one with the moral process, since the latter is a continuous passage of experience from worse to better" (RIP, 183). Attitudes central to educational learning are also moral qualities-"Open-mindedness, single-mindedness, sincerity, breadth of outlook, thoroughness, assumption of responsibility for developing the consequences of ideas which are accepted"' (DE, 356-357)-and "The teacher who operates in this faith [that these moral principles are 'inherent in community life' will find every subject, every method of instruction, every incident of school life pregnant with ethical life" (Archambault, 138).

Moreover, genuinely educational ideas and values which promote growth cannot be inert, apart from the rest of life, in the individual or the community: we act on what we know; what we value concerns what we do and the consequences. Learning about morality and about moral reasoning do not automatically translate into "good character or good conduct" (MPE, 1): "The business of the educator-whether parent or teacher-is to see to it that . . . ideas . . . are acquired in such a vital way that they become moving ideas, motive forces in the guidance of conduct' (MPE, 2).

So, for Dewey, the teacher is a social servant building a moral society: 
The moral responsibility of the school, and those who conduct it, is to society. The school is fundamentally an institution erected by society to do a certain work,- - to exercise a certain specific function in maintaining the life and advancing the welfare of society. The educational system which does not recognize that this fact entails upon it an ethical responsibility is derelict and a defaulter. It is not doing what it was called into existence to do, and what it pretends to do. (MPE, 7)

Prophet. What are we to make of Dewey's claim that "the teacher is always the prophet of the true God and the usherer in of the true kingdom of God" (Archambault, 439) if teachers and schools have historically played such a limited role in introducing progressive social change and can expect only a limited role? "Schools are, indeed, one important method of the transmission which forms the dispositions of the immature; but . . . only one means, and, compared with other agencies, a relatively superficial means"' (DE, 4).

It is as important not to underestimate the importance of the teacher and the school, and so, to fail to use them as it is not to overestimate them. Though the teacher is one citizen among many and the school one institution or social force among many, they are major formers of the thinking and experience of future citizens; this power is enormous and dangerous if not subject to the requirements of thinking well:

It is not whether the schools shall or shall not influence the course of future social life, but in what direction they shall do so and how. In some fashion or other, the schools will influence social life anyway. But they can exercise such influence in different ways and to different ends, and the important thing is to become conscious of these different ways and ends, so that an intelligent choice may be made, and so that if opposed choices are made, the further conflict may at least be carried on with understanding of what is at stake, and not in the dark. (Ratner, 694)

Here schooling is not just the learning of a prescribed curriculum. Thus, we hear echoes of the prophetic voice of Jesus when Dewey stated:

What avail is it to win prescribed amounts of information about geography and history, to win ability to read and write, if in the process the individual loses his own soul: loses his appreciation of things worth while, of the values to which these things are relative; if he loses desire to apply what he has learned and, above all, loses the ability to extract meaning from his future experiences as they occur? $(\mathrm{EE}, 49)$

Growth is the goal of education, of life, and of the good society. Their values are intimately linked:

Government, business, art, religion, all social institutions have a meaning, a purpose. That purpose is to set free and to develop the capacities of human individuals without respect to race, sex, class or economic status. And this is all one with saying that the test of their value is the extent to which they educate every individual into the full stature of his possibility. Democracy has many meanings, but if it has a moral meaning, it is found in resolving that the supreme test of all political institutions and industrial relations shall be the contribution they make to the all-round growth of every member of society. (RIP, 186)

Schools which realize that mission will indeed usher in a new era. As Dewey saw it, they must because of the nature of human beings, society, and education: the teacher is not just a prophet but creator and artist. 
Artist. As there is a large sense of community behind the three narrower senses of immediate concern in education and a large sense of continuity and interaction behind the various analogies, so there is a larger sense of experience which we may express in terms of experience and education as art and the teacher as artist. There is a flow, a continuity, to experience-it is always part of a larger whole-but some ways of grouping elements or breaking up this flow give meaning and significance to it and to our lives: we can talk of an experience as having an integrity, a unity. Revealingly, we say that we make something of it: we make and a thing is made. Like the artist, we create an integrity in the flow. Education creates order, meaning, and significance out of chaos-or, rather, empowers us through a knowledge of the implications and ramifications of our actions and possible actions to create and control even our lives:

the teacher is a trainer of mind, a former of character; an artist above nature, yet in harmony with nature, who applies the science of education to help another to the full realization of his personality in a character of strength, beauty, freedom .... (Archambault, 197)

For Dewey, it is not a cliche to say that "Knowledge is power and ... achieved by sending the mind to school to [study] nature and learn her processes of change" (RIP, 49) nor that art and science go together: "Nature is an artist that works from within instead of without. Hence all change, or matter, is potentiality for finished objects" (EN, 92). The wise and proper exercise of power depends on understanding the laws of nature to produce change and to anticipate and choose among the consequences of our possible actions. Like the artist, the educator has "the problem of creating something that is not the exact duplicate of anything. .." (Archambault, 7), and the challenge in teaching is to find stimulating, revealing, and manageable problems $(\mathrm{DE}, 157)$. The art of the teacher for Dewey is, thus, the supreme art "giving shape to human powers and adapting them to social service. .." (Archambault, 438). Power is neither artificially imposed on nature (like the artist, we learn the consequences and possible consequences of courses of action) nor merely copied from her (we also choose and control our actions).

So, we see Dewey's respect for the child and her free activity: the child is an artist, not a demon, naturally seeking meaning, significance and order and so making education possible. Interests, impulses, and needs are not to be pampered but guided by the teacher-the artist above nature-into new, worthwhile experiences and understandings which contribute to genuine growth. "The teacher's own claim to rank as an artist is measured by his ability to foster the attitude of the artist in those who study with him, whether they be youth or little children" (HWT, 288).

\section{Conclusion}

As developments of his understanding of democracy and education as growth, Dewey's seven analogies and his four conceptions of the educational community give us a rich, comprehensive, and coherent context in which to locate, and so understand and assess, claims about roles and responsibilities of teachers, teaching, schools, and the larger network of relationships with the family, other institutions, and the social group. They respond too to our intuitive 
sense of the complexity of such discussions and the seemingly competing nature of claims on the teacher's time, loyalties, and commitments. Above all, they draw attention to the central educational criteria, justifying an optimism in teaching based on the belief that the right reasons are educational ones when these are correctly understood. "The fundamental issue is ... a question of what anything whatever must be to be worthy of the name education."

The educational system must move one way or another, either backward to the intellectual and moral standards of a pre-scientific age or forward to ever greater utilization of scientific method in the development of the possibilities of growing, expanding experience. I have but endeavored to point out some of the conditions which must be satisfactorily fulfilled if education takes the latter course. (EE, 89; italics added)

The result is an understanding of the teacher's role which is both simpler and harder: "the new education is simpler in principle than the old ... in harmony with principles of growth . . . But the easy and the simple are not identical" (EE, 30) especially when the simple is new, not widely understood, open to misunderstanding and not part of our conventional ways of thinking and traditional practices (EE, 90). Contrary to the "quick fix," the instant panacea, Dewey maintained that

A reorganization of education so that learning takes place in connection with the intelligent carrying forward of purposeful activities is a slow work. It can only be accomplished piecemeal, a at a time. But this is ... a challenge to undertake the task of reorganization courageously and to keep at it persistently. (DE, 137; italics added)

So, we have a way of situating and assessing our original list of educational reforms. It becomes difficult to judge the merits of charter schools without looking at the educational provisions of particular charters; but, as with privatization, commitment to the larger senses of community may be at risk. Paideia proposals risk generalizing the importance of funded experience as the ultimate basis for the curriculum, confusing it with theories of learning and the design of promising classroom experiences. Customer-oriented models, those borrowed from business, and those stressing employability and national economic growth are in danger of failing to make central the educational ideals of growth, expanded experience, and increasing capacity for growth; they may rightly recognize the important influence of economic factors in educational policies, practices, and goals and the need for a credible education to provide a realistic, practical preparation for the lives students will lead after their schooling, but they risk failing to provide the context for discussing the difference between genuine and felt needs and short- and long-term interests. On the other hand, site-based management, cooperative learning styles, local community involvement, and a common curriculum ${ }^{6}$ have the potential, if well implemented and in the right spirit, for building classroom, school, local and larger communities in which the appropriate kinds of growth could occur.

Dewey's insights suggest that reconceptualizations and reorientations of education based on a single factor-the information age, the changing nature of knowledge, the changing nature of society or a new conception of intelligence-are almost certain to be misleading, though the central place of epistemology in Dewey's thinking forces us to ask about the appropriateness of 
Dewey's conception of the scientific method (Greene, 1994), the nature of thought, and so, the epistemological basis of his conception of education. Dewey's perspective enables us to bring much recent thinking but also much common sense to the solution of complex social and educational problems.

\section{Notes}

An earlier version of this paper was presented at the Society for the Philosophy and History of Education, Fayetteville, AR, September 1994. Educational Reform: A Deweyan Perspective written by these authors will be published by Garland Publishing in 1996.

References to Dewey's writings use common abbreviations for his works; abbreviations and editions used are noted in the References.

\section{References}

The following abbreviations have been used in the text:

DE -- Democracy and Education

$\mathrm{EE}$-- Experience and Education

EN -- Experience and Nature

HWT -- How We Think

LW -- John Dewey: The Later Works

MPE -- Moral Principles in Education

MW -- The Middle Works of John Dewey

PP -- The Public and its Problems

QC -- The Quest for Certainty

RIP -- Reconstruction in Philosophy

SS/CC -- The School and Society and The Child and the Curriculum.

Archambault, R. D. (ed.) (1964). John Dewey on Education: Selected Writings. New York: The Modern Library.

Buchmann, M. \& Floden, R. E. (1993). Detachment and Concern: Conversations in the Philosophy of Teaching and Teacher Education (Advances in Contemporary Educational Thought, vol. 11). New York: Teachers College Press.

The Common Curriculum (Working Document) (February, 1993). Toronto: Ministry of Education and Training, Ontario.

Covert, J. R. (1993). Creating a Professional Standard of Moral Conduct for Canadian Teachers: A Work in Progress. Canadian Journal of Education/Revue canadienne de l'éducation, 18(4), 429-445.

Dewey, J. (1896). The Reflex Arc Concept in Psychology. Psychological Review, 3(4), 357-370.

Dewey, J. (1909). Moral Principles in Education (Riverside Educational Monographs, Henry Suzzallo, Ed.). Boston: Houghton Mifflin Company.

Dewey, J. (1927). The Public and its Problems. New York: Henry Holt and Company, Inc.

Dewey, J. (1929). Experience and Nature (new edition). New York: Dover Publications, Inc. (Original work published 1925) 8(2), (Spring) 1995 
Dewey, J. (1933). How We Think: A Statement of the Relation of Reflective Thinking to the Educative Process (new edition). Lexington, MA: D. C. Heath. (Original work published 1910)

Dewey, J. (1948) Reconstruction in Philosophy (enlarged edition). Boston: Beacon Press. (Original work published 1920)

Dewey, J. (1966). Democracy and Education: An Introduction to the Philosophy of Education. Toronto: Collier-Macmillan Canada Ltd. (Original work published 1916)

Dewey, J. (1972). Experience and Education (The Kappa Delta Pi Lecture Series). New York: Macmillan Company. (Original work published 1938)

Dewey, J. (1990). The School and Society and The Child and the Curriculum. Chicago: University of Chicago Press. (Original work published $1956[1900,1902])$

Dill, D. D. (1990). What Teachers Need to Know: The Knowledge, Skills, and Values Essential to Good Teaching. San Francisco: Jossey-Bass Publishers.

Dworkin, M. S. (ed.) (1959). Dewey on Education: Selections with an Introduction and Notes (Classics in Education, No. 3). New York: Columbia University.

For the Love of Learning: Report of the Royal Commission on Learning. A Short Version (1994). Toronto: The Queen's Printer for Ontario.

Freire, P. (1970). Pedagogy of the Oppressed. New York: Seabury Press.

Fullan, M. G. (with Suzanne Stiegelbauer) (1991). The New Meaning of Educational Change. Toronto and New York: OISE Press and Teachers College Press.

Giroux, H. A. (1988). Schooling and the Struggle for Public Life: Critical Pedagogy in the Modern Age. Minneapolis, MN: University of Minnesota Press.

Goodlad, J. I. (1990). Teachers for our Nation's Schools. San Francisco: Jossey-Bass Publishers.

Goodlad, J. I., Soder, R., \& Sirotkin, K. A. (1990). The Moral Dimensions of Teaching. San Francisco: Jossey-Bass Publishers.

Greene, M. (1994). Epistemology and Educational Research: The Influence of Recent Approaches to Knowledge. In L. Darling-Hammond (Ed.), Review of Research in Education, 20 (chap. 10, pp. 423-464). Washington, DC: AERA.

Hare, W. (1990). Limiting the Freedom of Expression: The Keegstra Case. Canadian Journal of Education/Revue canadienne de l'education, 15(4), 375-389.

Hare, W. (1993). What Makes a Good Teacher: Reflections on Some Characteristics Central to the Educational Enterprise. London: Althouse Press.

Hawley, W. D. \& Rosenholtz, S. J. with Goodstein, H. \& Hasselbring, T. (1984). Good Schools: What Research Says about Improving Student Achievement [Special Issue]. Peabody Journal of Education, 61(4).

Holmes Group. (1986). Tomorrow's Teachers: A Report of the Holmes Group. East Lansing, MI: The Holmes Group, Inc.

hooks, b. (1994). Teaching to Transgress: Education as the Practice of Freedom. New York: Routledge.

John Dewey: The Later Works, 1925-1953 (Vol. 4, 1929) (1988). Carhgndale and Edwardsville, IL: Southern Illinois University Press.

Paideusis 
McQuaide, J. \& Pliska, A-M. (December 1993-January 1994). The Challenge to Pennsylvania's Educational Reform. Educational Leadership, 51(4), 16-21.

The Middle Works of John Dewey, 1899-1924: Vol. 7. Essays on Philosophy and Psychology, 1912-1914 (1985). Carbondale and Edwardsville, IL: Southern Illinois University Press.

Perkinson, H. J. (1993). Teachers Without Goals. Students Without Purposes. New York: McGraw-Hill, Inc.

Ratner, J. (Ed.) (1939). Intelligence in the Modern World: John Dewey's Philosophy. New York: The Modern Library.

Sockett, H. (1993). The Moral Base for Teacher Professionalism. New York: Teachers College Press.

van Manen, M. (1991). The Tact of Teaching: The Meaning of Pedagogical Thoughtfulness. Albany, NY: SUNY Press. 